\title{
Organisational and Financial Determinants for the Metropolitan Rail Transport Implementation in Poland with Potential Improvement Prospects
}

\author{
Paweł PODLEŚKO무 ${ }^{1}$ Tomasz WARSZA ${ }^{2}$
}

\begin{abstract}
Summary
The article addresses the issue of financing and organising metropolitan rail transport. It identifies challenges for this segment, which include the absence of organisational and funding obligations on the part of metropolitan government structures. It describes the forms of vertical co-operation which are legally permissible for local government units and identifies the drawbacks in this respect. It cites the examples of management of the metropolitan railway transport in Poland, operated despite the existing restrictions. The absence of complete legal and financial instruments providing metropolis with legal certainty in the organisation of metropolitan transport is identified. Specific solutions are recommended, referring to information on dealing the described problem outside Poland.
\end{abstract}

Keywords: public transport organisation, rail transport, metropolitan areas, integration of offers+, combined ticket

\section{Introduction}

Among the officially declared objectives for the development of passenger rail transport in Poland is (...) the development of daily commuting systems integrating urban centres into metropolitan systems and enhancing the range and functional areas of cities and creating network links between existing urban centres in peripheral areas threatened with marginalisation, including improvement of the capacity of city transport hubs (...) [8, p. 75]. Therefore, it points to the need to develop organisational, operational, and financial conditions for the development and implementation of the rail transport categories commonly referred to as "metropolitan" [8, p. 31, p. 112].

Officially, according to Polish law, metropolitan rail transport should be regarded as the closest to metropolitan passenger transport as stipulated in Article 4 (1) (5a) [16] (hereinafter: Public Transport (PT) Act). In fact, metropolitan rail transport operates as a special type of regional passenger transport. It covers the transport of passengers within the administrative borders of at least two poviats (poviat - Polish equivalent of county) and not extending beyond the borders of one voivodeship (region) with finan- cial and organisational involvement of local poviat, gmina (borough / community) and even voivodeship government units. Metropolitan passenger transport covers public transport services provided within the boundaries of a metropolitan union; other than gmina, poviat, poviat/gmina, voivodeship and interregional transport.

The article describes both the current complex organisational and financial framework for the provision of passenger rail services considered as metropolitan rail transport and the essential conditions for their improvement. This is justified by the results of demographic analyses and the specific nature of metropolitan rail transport combining the characteristics of both public transport and traditional passenger trains.

\section{The essence of the issue concerning the organisation of metropolitan rail transport}

The obligation to organise rail passenger transport in Poland is imposed directly on two levels of public transport organisers: the minister responsible for

\footnotetext{
${ }^{1}$ Dr; Ministry of Development Funds and Regional Policy; e-mail: Pawel.Podlesko@mfipr.gov.pl.

${ }^{2}$ Mgr; Office for Railway Transport; email: tomasz.warsza@gmail.com.
} 
transport (international and inter-regional transport) and voivodeship marshals (regional transport). At the same time, the legislator provided sources of funding for regional and inter-regional transport. As a result of the requirement to finance regional rail transport, in the years 2003-2009, voivodeship authorities were provided with a $1.5 \%$ share in CIT revenues for this purpose, while since 2010 this share has been increased by another $0.75 \%$ and amounts to $2.25 \%$ in total. Pursuant to Article 3 [12], the level of funding of voivodeship governments for railway transport was increased by $0.75 \%$, raising the total percentage share of voivodeship governments in revenues from this source from $14 \%$ to $14.75 \%$.

Other categories of organisers, either at the level of local governments or structures created by them (union of gminas, union of poviats, union of gminas and poviats or metropolitan union) are not obliged to organise railway services.

Although the provisions of the PT Act, Article 4, and Article 7 [16], do not exclude this option, the lack of funding sources for the organisation of such services naturally results in the limited range of operations of gmina, poviat and metropolitan PT organisers within the field of rail transport. However, an organiser such as a metropolitan union, which is naturally predestined to organise rail passenger services, is not legally obliged to provide its residents with access to rail services, because there is no statutory obligation to do so on its territory.

At the same time, it should be underlined that, in the public transport development planning process on the territory of a given organiser, it is necessary to consider the needs of the sustainable development of public transport (Article 12, section 2, item 4 of the Act on Public Transport), but this concept is quite generally defined in the Act on Public Transport itself. They are defined as those that consider the social expectations with respect to ensuring public transport services generally accessible, aiming at the use of various means of transport, as well as those which promote environmentally friendly means of transport equipped with modern technical solutions, Art. 4 item 1, section 28 [16]. With this conceptualisation of transport in metropolitan areas, it refers primarily to the provision of municipal public transport services, understood as public transport operated with a variety of rolling stock (bus, trolleybus, tram, and underground) managed by the municipal transport companies operating in a given organiser. It does not, however, include the integration of different organisers' offers at different levels and in different modes of transport as an objective which should be served by the sustainable development of public transport. The principle of mutual agreement on transport lines by neighbouring organisers, Article 13 [16], as well as the principle of incorporating the provisions of higher-category transport plans, Article 11 [16], are also formulated in such a general way as to promote the inter-sectoral integration of the offers only by highly cooperative organisers.

Admittedly, in the case of a metropolitan union, an obligation was introduced for it to establish an integrated ticketing system valid within its boundaries (Article 15a of the PT Act), but it had no obligation to organise rail transport ${ }^{3}$. This means that the integrated ticketing system defined in the PT Act (Article 4, section 1, item 26) does not, of course, forbid the inclusion of rail transport in the metropolitan offering, but neither does it explicitly require it. It is a solution whereby a passenger may use a ticket entitling him to use different modes of transport in an area of operation of a public transport organiser. In addition, neither the PT Act nor the rail transport regulations include any regulations constituting tools that would allow the effective integration of rail transport into an integrated ticketing system. Therefore, in practice, such a system may primarily involve the integration of underground, bus, tram, and trolleybus services provided by different-category organisers forming a union.

The complex statutory reduced fare program, valid separately and in different rates in rail transport and in public (municipal) transport, in which reduced fares are granted and financed exclusively by local government organisers, is compounded by the differentiation of reduced fares according to train category [62]. As a result, the reduced fare program in public transport includes statutory reduced fares (refinanced from the state budget), the so-called local government reduced fares and trade allowances which result from the commercial policy of each operator and are granted by them arbitrarily under commercial terms [40]. This, in turn, affects the different sources of compensation to operators for revenue lost due to the reduced fares applied.

The complexity of this system leads to a situation where the regulation of reduced fares on public transport is included in about 20 acts of common legislation (laws and regulations), not including local acts of law [60]. At the same time, the current legislation excludes the option to combine statutory reduced fares with trade discounts. The statutory reduced fares themselves combine both the nature of compensatory social benefits (discounts for pensioners, the disabled persons and students) and discounts for those per-

$\overline{{ }^{3} \text { Pursuant to Article }}$ 1(2) of the revoked [14], a metropolitan union still has no such obligation. 
forming certain public functions (e.g., for officers of uniformed services while performing their official duties) [29]. In addition, due to the separate "assignment" of statutory reduced fares not only across different types, but even across public transport modes or across train categories, the use of common (e.g., on express trains and municipal public transport) fares and tickets is hampered. The common legislation does not provide for direct compensation for the combination of statutory and commercial discounts when a traveller buys one ticket but for different modes of transport [33, p. 16]. Although there are formal grounds in Polish legislation for offering passengers the option to purchase a single ticket for an entire journey, irrespective of the number, modes and types of transport used during the journey (Article 6, section 1) [15], in practice, the initiative in this respect depends entirely on the resourcefulness of public transport organisers and operators, without any financial incentives to create such solutions. As a result, organisers and operators are even penalised for implementing initiatives as they lose revenue from statutory reduced fares when rail transport is integrated. They do not profit from the state budget in return. It is difficult to accept that national and EU development objectives for public transport are pursued in this way.

The described aspects indicate why the system solutions adopted in the PT Act can be directly applied to only very cooperative organisers remaining at the same level of local government. The current legislation seems to stick to a branched (or even siloed) view of public transport, leaving the potential harmonisation of the offers of the different modes to the initiative of the organisers. On one hand, this is somewhat understandable since, in principle, it is difficult to decree economic cooperation in any area top-down. On the other hand, however, the lack of a stable, formal legal framework practically prevents the full integration of rail transport into municipal passenger transport systems and affects the legal certainty of the measures taken. For rail services, commonly referred to as "metropolitan", the integration not only of infrastructure, but mainly of fares, into municipal public transport is crucial. This, in turn, requires an intersectoral approach to understanding accountability for their development.

\section{Organisational solutions for metropolitan rail transport applied in Poland}

National legislation, as stated in the introduction, does not distinguish such a category of transport as metropolitan rail transport. However, there are quite a few definitions in the literature that define this cat- egory. To designate them, for example, Anglo-Saxon literature (sometimes interchangeably) uses the term "commuter rail" or "transit rail." The former term usually refers to railways serving residents (commuters), [17, p. 244] travelling daily for study or work from suburban districts of an urban area, from neighbouring metropolitan areas and from functional areas of an urban area to its centre [1, p. 16].

This type of railway system is characterised, among others, by: regularity (timetable synchronicity) and high train service frequency in the metropolitan area, often functionally separated railway infrastructure serving only these trains, long-term ticket-based journeys, focus on providing passengers with access to one or two main stations located in the largest business districts of a metropolitan area, a fare system separated from long-distance train traffic, and zonal station service (i.e. servicing certain stops and stations only at specific times of the day and week). The commuter rail operator is often a railway operator that also provides its transport services in other areas of a region/country and treats commuter rail as part of its offers. Examples are: the Norwegian Lokaltog Østlandet (Oslo metropolitan railway) providing services to Oslo and Gardermoen airport and to the eastern part of the country, which is operated by the Norwegian state-owned operator (Vygruppen) [64], or the system of so-called Electriczkas (broad-gauge rail), which operate, among others, in the metropolitan area of Riga and are operated by the Latvian stateowned operator [54].

Examples of commuter rail, often referred to in the literature, are also German, Austrian, or Danish S-Bahn systems (Schnellbahn, Stadtbahn, and Stadtschnellbahn) [24, p. 21]. However, the assignment of the $\mathrm{S}-\mathrm{Bahn}$ to the commuter rail category is primarily due to the infrastructure aspects of this type of rail service, and to a lesser extent to the functional characteristics it has. In the case of Berlin, the S-Bahn, while remaining under the national holding of the German railway DB AG, is part of the offer of the Verkehrsverbund Berlin-Brandenburg (VBB), i.e., an association of various transport enterprises in the states of Berlin and Brandenburg and the cities of Cottbus, Frankfurt (Oder) and Potsdam. In terms of area, VBB is one of the largest transport networks in Europe. In the VBB area, the same ticket can be used throughout the transport system: S-Bahn, U-Bahn, tram, bus, underground and ferry [56]. The S-Bahn system is, in fact, a ticketing integration of a separate rail operator into the VBB offer.

So called "transit rail" involves services organised on similar infrastructure principles as commuter rail, but it is usually a system operating over shorter distances within metropolitan areas themselves at even higher service frequencies. It serves all successive 
stops on the line and therefore achieves lower commercial speeds, but with trains that have higher acceleration and provide a faster exchange of passengers at the stops $[28, \mathrm{p} .41]^{4}$. In general, however, what seems to distinguish transit rail is the fact that this type of rail service is organised by local (metropolitan) passenger transport organisers, and that it is fully integrated into the ticketing system of metropolitan public transport, which gives it the characteristics of an "underground rail." An example of this is Transport for London, where (with a few exceptions) city fares apply to rail services within the London metropolitan area [61]. A similar situation also applies to Berlin, which is why the information about the incorporation of the S-Bahn into the commuter rail category was given a conditional annotation [39].

The first option (commuter rail) is traditional regional commuter rail with its own ticketing system, meeting the transport demand of regional residents in an area larger than just a metropolitan area itself. It is a type of regional service that provides services to large cities. The metropolitan nature of this type of transport is mainly reflected in the following aspects: infrastructure (often functionally and proprietary separated infrastructure) and suprastructure (rolling stock dedicated to these services). In Poland, the example of Warsaw Commuter Rail (Warszawska Kolej Dojazdowa sp. z o.o. - WKD) can be cited as a model case in this respect.

WKD is owned by the Mazovian Voivodeship, the City of Warsaw and the six gminas lying along its route. At the same time, the Mazovian Voivodeship is the only entity ordering and paying for transport services performed by WKD. The described situation shows how complicated the situation is in Poland as regards the organisation of metropolitan transport. It requires that the authority in charge of regional transport also be involved. Another example is Szybka Kolej Miejska (TriCity) (PKP Szybka Kolej Miejska w Trójmieście sp. z o.o. - PLP SKM) (PKP SKM), which retains fares separate from those of the city, although partially accepting them. PKP SKM is owned by PKP S.A., the Pomeranian Voivodeship and the local authorities of Gdansk, Sopot, Gdynia, Pruszcz Gdański and Rumia.

The second option (transit rail) is a truly metropolitan railway, which is integrated in terms of infrastructure, fares, and ticketing into the municipal (metropolitan) public transport system. In such a sys- tem, the nuisance of transfers is minimised by the functioning of a single metropolitan transport system, which also fully encompasses rail services provided by a metropolitan organiser and allows for free interchange of transport modes without incurring additional charges or having to know the (usually complex) fares and offers of the railway operators. In this context, the metropolitan character derives not only from the infrastructural and suprastructural aspects, but also from the organisational aspect, meaning the provision of services for the municipal (metropolitan) public transport organiser and their incorporation into the metropolitan ticketing system. The Warsawbased Szybka Kolej Miejska sp. z o.o. can be cited as a Polish example (SKM Warszawa).

The problem of defining metropolitan rail transport has also been raised in Poland. Referring to the studies of international organisations operating in the field of rail transport, Polish studies have indicated not only the functional characteristics of metropolitan transport, but also the range of travel (in terms of time and space), high frequency of services or small distances between stops [30, p. 37], [25, p. 172]. According to the terminology used in official public statistics by the regulator of the railway market in Poland (the President of the Office for Railway Transport hereinafter referred to as the ORT President), metropolitan transport is (...) services which are intended to satisfy the transport needs of a large urban centre / conurbation / metropolitan area, as well as the transport needs between such a centre and neighbouring areas; the frequency of metropolitan trains is high (usually at least 4 trains per hour), the distance between stops is relatively short and the network is strongly linked to the network of other public transport modes; trains are designed to carry a large number of passengers and enable them to be efficiently exchanged, unlike regional services which aim to meet the transport needs of an entire region (...) [30]. [30, p. 37]. The definition quoted above shows that the terminology also distinguishes between transit rail, which is comprehensively integrated with municipal metropolitan transport, and traditionally interpreted commuter rail.

On the basis of international experience with metropolitan transport, taking into account national conditions in this respect and specifying the term used by the ORT President ${ }^{5}$, the following definition of metropolitan rail transport can be formulated: (...) is a system of railway infrastructure, rolling stock as-

\footnotetext{
${ }^{4}$ Detailed information on the operational characteristics and functionality of rolling stock designed for this type of service is the subject of separate studies [26].

${ }^{5}$ Terminology used in the systematic reporting by the ORT President has a special character because it is industry-specific terminology, allowing obliged entities (in this case railway operators) to easily identify and assign their activity to a specific category, distinguished for statistical purposes. Hence, the article suggests an extended definition, also considering the organisational aspects of transport.
} 
signed to it, passenger departure facilities (stations and stops) and transport organisation in an urban area and their functional areas, characterised by high frequency of service, frequent train stops in a dense network of stops, continuous train services, as well as the integration of services into a municipal (metropolitan) ticketing system (...). It should also be mentioned that the proper functioning of metropolitan rail transport requires that selected train stopping locations (usually outside the very centre of a metropolitan area) are equipped with park-and-ride facilities, which would prevent the inflow of passenger cars to the centre of a metropolitan area and enable their replacement by public transport, i.e., rail transport [57].

Defining metropolitan transport services with the use of maximum travel distances and travel times (often defined as trips of no more than $15 \mathrm{~km}$ and lasting no more than 30 minutes) [20, p. 17], seems to be less relevant in this case. This is due to the global trend towards suburbanisation and the urban sprawl (usually uncontrolled) of large cities. As a result, even longer than 30-minute journey times can take place within the same city. For example, a journey from London Kings Cross to Hayes\&Harlington lasts around 55 minutes but still within the borders of London and is based on the fares binding in the city [51]. For this reason, a more reliable indicator of the "metropolitan character" of rail passenger transport seems to be the clear regularity, cyclical nature and equality in distance of train routes, which cause them to take over the functions of public transport - especially due to their incorporation into the metropolitan ticketing system. This means that, in metropolitan transport, trains on individual routes run even in a cycle (times, intervals) every few minutes, adapted to circular migration and traffic intensity during peak hours [34].

In Poland, metropolitan areas are areas around voivodeship cities [32, pp. 173-175]. Originally, such areas were distinguished in Koncepcja Przestrzennego Zagospodarowania Kraju (National Spatial Planning 2030 Concept) [9] (KPZK). This document outlines, inter alia: a vision of the country's spatial planning until 2030, defines the goals and directions of the country's spatial planning policy, and indicates the principles according to which human activity should be implemented in space. Metropolitan areas are defined as: (...) an area of a country distinguished based on common geographical features and strong internal links. An example of a functional area can be a large city and the surrounding boroughs. Residents of these boroughs commute to work in the city daily, study there, go to the theatre etc. This means that such an area has a common potential and development barrier, independent of administrative borders (...) [49].

The following areas have been included on this basis: Warsaw and the Upper Silesian Urban Area (Katowice with the cities included in the Metropolitan Association of Upper Silesia and Dąbrowa), Łódź, Kraków, TriCity (Gdańsk - Sopot - Gdynia with the main urban centre in Gdańsk), Wrocław, Poznań, Szczecin, the emerging duopoly Bydgoszcz - Torun, Lublin and voivodeship cities of national importance, in which there is a systematic concentration of metropolitan functions of international and national significance: Białystok, Rzeszów, Opole, Olsztyn, Kielce, Gorzów Wielkopolski and Zielona Góra [49 p. 37]. In turn, according to the classification of the EU ESPON programme, developed in 2004, out of 76 so-called MEGA (Metropolitan European Growth Areas) occurring in Europe, one potential area of this type, the so-called Potential MEGA (Warsaw) and seven centres with poorly performing functions of metropolitan growth areas, the so-called Weak MEGA (Gdańsk-Gdynia, Kraków, Katowice, Poznań, Wrocław, Szczecin, and Łódź) are mentioned [23, pp. 81-86]. The detailed range of these areas is illustrated by a map which, due to editorial constraints, is not included, cf. [49].

Currently, according to the Partnership Agreement, the key urban centres in the country are the areas of voivodeship cities and their functional areas [47], which in turn are delimited in detail in individual voivodeship contracts concluded by the Council of Ministers with each of the voivodeship [3, p. 177]. The Partnership Agreement is a form of contract between a particular EU Member State and the European Union itself (acting on its behalf, the European Commission), which sets out the directions of intervention in the years 2014-2020 for the three EU policies: the Cohesion Policy, the Common Agricultural Policy, and the Common Fisheries Policy, in such a way that they contribute to the implementation of the EU's EUROPE2020 strategy in each country [45].

In Poland, particularly intensive processes of metropolitan development are visible, among others, in the areas around Warsaw, Krakow, the TriCity, Poznań, Lublin and Wrocław $\left[27\right.$, p. 221] and $[22]^{6}$. However, demographic and urbanisation processes are not accompanied by the development of institutional forms of support for metropolitan rail transport ${ }^{7}$. An important problem, overlapping with the lack of availability

\footnotetext{
${ }^{6}$ Hence, a representative group was used for further analysis: Poznań, Warsaw and Kraków.

${ }^{7}$ The establishment of a metropolitan union requires the adoption of a law intended for a specific union [10]. Besides, the very establishment and functioning of metropolitan unions is not regulated in detail by law.
} 
of metropolitan transport financing and organisation, is the limited catalogue of legal forms intended for organisers and operators of various levels who jointly want to provide rail transport integrated with other transport services in public transport within an urban area. In this respect, local government units are bound by law allowing the following options: an internal organisational unit, a separate budget unit created by an organiser, a private limited company (including a municipal company), an association and a union of local government units ${ }^{8}$. The solution whereby an internal unit or a separate budgetary unit is established in a given office to serve all the other local government units at various levels within an urban area is legally unacceptable.

Pursuant to Article 15 (1) [16], the organiser's tasks include ensuring appropriate conditions for the operation of public transport. It follows that, for individual local government units, the PT organisation is the responsibility of a respective local government unit. Admittedly, in accordance with the regulations on the gmina government, the performance of public tasks by gminas may take place through cooperation with other units of local government. In addition, gminas, unions of gminas and associations of local government units may aid each other, including with financial assistance. However, there is no legal option for a local government unit to completely delegate its own tasks to other local government units of a higher level.

On the other hand, private limited companies are aimed programme-wise at achieving the economic goals of their shareholders and not at satisfying the collective needs of the local community [31]. This does not, of course, exclude the establishment of private limited companies with the participation of local government for the public transport organisation. However, it should be remembered that a company is a separate entity from its founders in both civil and administrative relations. A company trades in its own name, has its own corporate bodies and is liable for its debts with its own assets. Relations between a local government unit and an established company are based on civil law premises. Thus, both a local government unit and a company retain autonomy.

The regulations on municipal management shape the issue of the existence of a supervisory board differently and stipulate that "there is a supervisory board operating in companies with the participation of local government units". Other provisions of the Commercial Companies Code on the functioning of companies shall apply mutatis mutandis to a company with the participation of local government units. According to the Supreme Audit Office (SAO): (...) In the audited gminas and voivodeships, performance of public tasks of local government units by means of companies created by them was, in the opinion of the SAO, burdened with many irregularities such as: undertaking projects without reliable preparation (lack of economic analyses, lack of estimation of required resources, failure to take account of existing risks), failure to ensure professional and effective performance of tasks, as well as management of assets inconsistent with statutory objectives. During the audit, cases of failure to ensure organisational and financial conditions for the implementation of the tasks entrusted and lack of diligence in reducing the costs of the performed operations, and thus the costs of implementing public tasks, were also identified. The performance of local government tasks by the companies broadened the organisational and financial potential for their implementation, but irregularities in the operations of the companies had a negative impact on the effectiveness and efficiency of such operations. In the opinion of the Supreme Audit Office, the implementation of public tasks by the audited gmina and voivodeship governments performed by companies established by them was not effective. Irregularities, both in the establishment of companies and in their management of assets, as well as in the performance of individual tasks by companies, have reduced the effectiveness of the implementation of local government tasks. In addition, the audit found cases where there was no legal basis for some companies to perform operations in particular areas (...) $[4$, p. 6].

The use of companies by local government units, in legal and economic operations, requires the involvement of professional staff experienced in the use of commercial regulations on the market for this form of activity. Meanwhile, local government units do not have the resources for this, and the organisation of metropolitan transport is not a market-oriented and profit-oriented activity. Considering the findings of the SAO from the aforementioned audit, local government units lack legal certainty as regards the permissibility of the use of private liability company forms in public utility operations. As far as the association formula is concerned, it should be noted that it is the only non-profit structure permissible for local government units, allowing local government units of any level and in various areas to become members. The main shortcoming of the association, however, is that it is not possible to transfer the powers of the public transport organisers from the local government units to the association. As far as unions of local government units are concerned, however, as has

\footnotetext{
${ }^{8}$ Pursuant to Article 7 [13], local government units are not entitled to establish state-owned enterprises.
} 
already been explained, none of its variants (unions of gminas, unions of poviats and gminas and metropolitan unions) is obliged to organise rail passenger services. Moreover, the transport operations of unions of local government units are among the many that these structures may perform. They are therefore not specialised legal forms intended to manage the complex matter of public transport.

As a result of the lack of institutional, financial, and legal forms and structures intended to support the development of metropolitan rail transport in Poland, PT organisers at various levels of local government unit are forced to look for solutions available to them, which would temporarily eliminate the existing system constraints. In addition to the already mentioned example of the WKD, the Poznan Metropolitan Railway (PKM) can also be cited here. This is a project involving the launch of passenger services operated by Koleje Wielkopolskie sp. z o.o. (KW) in the Poznan metropolitan area on the public railway infrastructure managed by PKP PLK S.A. The first five PKM lines connected Grodzisk Wielkopolski, Jarocin, Nowy Tomyśl, Wągrowiec and Swarzędz with Poznań. Ultimately, in Poznań, trains launched under the PKM project will stop at around 60 stations and stops. Already today, peak hour routes operate as often as every 30 minutes [53]. The project is a joint venture of the Wielkopolska Voivodeship, the City of Poznań, Poznań Poviat, the Poznań Metropolis Association and 40 communes and 10 poviats in Wielkopolska. The PKM covers an area within a radius of about $50 \mathrm{~km}$ from Poznań [58]. The Marshal of the Wielkopolska Voivodeship, as the organiser of regional passenger rail transport in Wielkopolska, has joined the PKM project together with one of its operators $-\mathbf{K W}^{9}$. This is an operator which, in principle, provides regional transport services in line with the PT regulations.

PKM operates on the principle of solidarity of participating local government units, which in practice includes their co-financing of stops on their area of regional trains launched by the Marshal. It involves all local authorities located along a given railway line providing a purpose-specific subsidy to the Wielkopolska Voivodeship to cover part of the costs of the launched railway services [21]. The incorporation of KW trains into public (municipal) transport is based on the acceptance, within the so-called railway zone A (i.e.: all Poznań stations and the Kiekrz station), of travel cards with zone A of the Municipal Transport
Authority in Poznan encoded on the Poznan Electronic Metropolitan Card (PEKA), Electronic Student Identification Card (ELS) or (ELD) [43]. In addition, KW offers, among others, the following: Bus-TramRail (BTR). This is a monthly rail ticket (valid in the so-called A-G zones in Wielkopolska), which is valid on KW and POLREGIO passenger trains and public (municipal) transport organised by the Transport Authority in Poznań. Passengers using bus transport in Gniezno can combine the BTK ticket - F zone with the offer of MPK sp. z o.o. in Gniezno [44]. Detailed information, including zone boundaries, is presented in Figure 1.

PKM operates as the above-mentioned type of "regional rail" / "commuter rail" based on the presented formula of the union of gminas and poviats, but with the participation of the Marshal that, performing its statutory tasks of the regional organiser, allowing mutual acceptance of some tickets, additionally ensures the service of specific local needs of the Poznan urban area ${ }^{10}$. Formally, however, PKM is a commercial offer of a regional railway operator, established to perform different transport tasks. It relies on the mutual acceptance of some tickets, which does not help to simplify the rail offer or the public transport offer and does not help to make them more comprehensible to passengers. This does not in any way diminish the role of PKM - on the contrary: it indicates the determination of Wielkopolska's local government units, which skilfully use the legal forms available to them to create a public transport offer that satisfies residents.

The Kraków Fast Metropolitan Railway (SKA) is another example of a commercial offer. It uses trains operated by Koleje Małopolskie Sp. z o.o. (Koleje Małopolskie). It is a system of rail connections ultimately covering Kraków and the northern part of the Małopolska Voivodeship on a generally accessible railway infrastructure managed by PKP PLK S.A. Currently, there are already three launched SKA lines connecting the Kraków Główny station with: Kraków Airport, Wieliczka Market Square-Mine, Sędziszów, Skawińskie Podbory, Trzebinia and Tarnów. Trains operated as part of the SKA project stop at 50 stations and stops. Rush hour services run every 30 minutes on crucial sections.

The project is an undertaking of the Małopolska Voivodeship and Kraków with the participation of the local governments of the gminas and poviats located on SKA routes. Individual gminas and poviats participate through their contributions to infrastructure

\footnotetext{
${ }^{9}$ It is important to note that in Wielkopolska regional transport organised by the Marshal is also provided by POLREGIO sp. z o.o.: see: [52].

${ }^{10}$ It should be clarified that the area of activity of the Association of Poznan Metropolis, in addition to transport, also includes culture, environmental protection, sport, education, family issues, seniors, health and economy [59].
} 


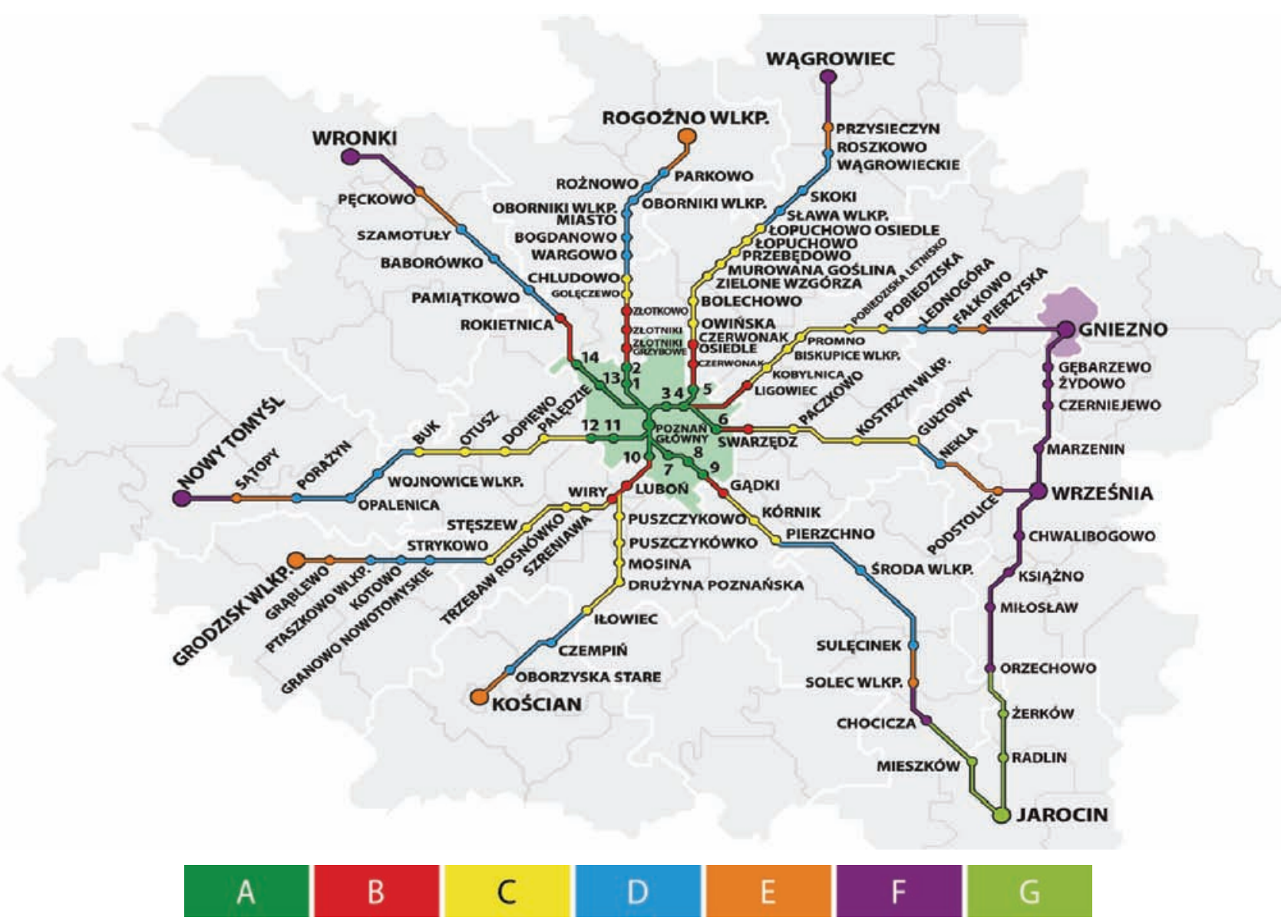

Fig. 1. Boundaries of BTK ticketing zones on railway lines [35]

projects for railway stations, stops and supporting infrastructure $[18,19,37,38]$. Similarly, as in the case of the PKM, the project of the Kraków metropolitan system had to be joined by the Marshal of the Małopolska Voivodeship as the organiser of regional railway passenger services in the Małopolska region, together with one of the operators running the trains ordered by it [38 ${ }^{11}$. However, the key element of the SKA is its ticketing integration with municipal transport. The SKA route is covered by the Małopolska Karta Aglomeracyjna (MKA) (Travel Card of Małopolska), which is a tool offering passengers convenient access to the extensive ticketing of the region's PT organisers and operators. In addition to tickets for trains organised by the Małopolska Voivodeship, the MKA system also offers access to public (municipal) transport tickets in towns and cities such as: Kraków, Tarnów, Nowy Targ, Zakopane and Wieliczka. As part of the MKA system, two modern media are available - a plastic proximity card (a travel card) and the free iMKA mo- bile application (single tickets and travel cards). Apart from the standard tickets, an integrated ticket (also an integrated monthly ticket) for trains and public transport in Gmina Kraków is valid on the Wieliczka Rynek Kopalnia - Kraków Główny and Wieliczka Rynek Kopalnia - Kraków Olszanica routes (from 1 to $20 \mathrm{~km}$ section). The Wieliczka Rynek Kopalnia stop, operated by Gmina Kraków, is accessible via the Commuter Bus Line, where a single ticket can be purchased for both the commuter bus and the train. Koleje Małopolskie accepts most tickets issued by POLREGIO on a reciprocal basis. Tickets of Koleje Małopolskie and Koleje Śląskie are also accepted on the Kraków Główny - Kraków Bronowice route and on the Nowy Targ - Zakopane route [42].

However, this does not change the fact that the commercial offer of the regional railway operator was also launched under the SKA banner. Another transport segment was added to the service, referred to as metropolitan. As a result, Koleje Małopolskie was

\footnotetext{
${ }^{11}$ POLREGIO also provides regional transport in Małopolska, organised by the Marshal.
} 
equipped with mixed rolling stock (for both regional and metropolitan services), which undoubtedly generates higher maintenance costs. SKA is also an example of commuter rail, a regional operator operating in a metropolitan area. The operator retains its own ticketing system and is additionally integrated into the ticketing system of individual areas of the Kraków metropolitan area. This does not, of course, change the fact that such a service is necessary for Kraków. The topography of this city is based, among other things, on its medieval buildings with the potential for redevelopment for traffic purposes being severely limited. The development of public rail transport is therefore a desirable alternative.

SKM Warszawa is a rail operator owned by the capital city of Warsaw. It is a part of Warsaw Public Transport in terms of function and fares. SKM Warszawa is the only example in Poland of a standard - gauge rail operator owned by a municipal government and providing a regular (scheduled) service to a metropolitan area. SKM Warszawa provides passenger transport services within the Warsaw metropolitan area on the existing lines managed by PKP Polskie Linie Kolejowe SA. The first rail link, the S1 line, was launched in 2005 on the Warszawa Zachodnia - Warszawa Falenica route. Currently, SKM Warszawa serves passengers on four $160-\mathrm{km}$-long routes, covering 53 stations and stops in the Warsaw metropolitan area. The service regularity, depending on the SKM Warszawa line, varies from about 30 to 60 minutes, while on some lines the departures are irregular.

As a result of ownership relations, SKM Warszawa is fully integrated with the ticket fares for municipal transport within the Warsaw metropolitan area: Warsaw Transport Authority (ZTM) tickets are valid on board its trains, and a passenger can use the same ticket (single ticket, long-distance ticket) not only on SKM Warszawa trains but also with other modes of transport operated by ZTM (bus, tram, and underground $)^{12}$. Currently, financing of transport services organised by ZTM (including those provided by SKM Warszawa) is provided from two basic sources: the city budget, including revenues from ticket sales, and subsidies from gminas with which agreements on the public transport organisation are in force [5].

In terms of financing public transport, Warsaw has developed the practice of entering into individual administrative agreements with the local governments of Warsaw's suburban gminas for the joint performance of local public transport tasks. This cooperation covers the launch of public transport as well as the maintenance of stations and stops and a common fare system. The baseline method for determining the amount of contribution to the costs of SKM Warszawa trains is the valuation of services based on the total train kilometres planned in the timetables of this operator's lines between specific railway stations and the unit fare per train kilometre established in the agreement [6].

\section{Propositions of legal and organisational solutions}

First, it is necessary to distinguish between the concepts of metropolitan railways, implemented as further commercial offers of regional operators, and metropolitan rail operators specialised in providing such services (SKM Warszawa) with their own separate infrastructure for this purpose (PKP SKM, WKD). For financial and organisational reasons, the development (created by the regional organiser - the Marshal) of further commercial offers for urban areas prevails in Poland - with the development based on the commuter rail model. In a situation where a rail operator is not owned by a municipal government, the regional Marshal, with its regional operator, must step in at the level of metropolitan transport. However, the competencies of Voivodeship Marshals include the organisation of other types of railway passenger services, which results, for example, in the fact that the rolling stock purchased by voivodeship self governments is, as a rule, designed for other transport needs than the metropolitan ones [26]. Thus, the Marshal is not able to support both regional and metropolitan areas at the same level. By choosing a system that generates a lower transport deficit (i.e., a metropolitan system), it in a way leads to a decline in the regional transport system, for which it is responsible by law.

The development of metropolitan transport systems in Poland, in one form or another, shows that despite the lack of national regulations defining metropolitan transport and a systemic way of its organisation and financing, local government units risk becoming involved in the construction of public passenger transport systems in functional areas of capitals of the voivodeships. In addition to the examples cited above, the following metropolitan rail system projects (of different nature), the implementation of which is progressing in Poland, should also be highlighted: Pomeranian in the TriCity, Szczecin Metropolitan

\footnotetext{
${ }^{12}$ Tickets of Koleje Mazowieckie sp. z o.o. are also accepted on selected routes - and vice versa, Koleje Mazowieckie accepts tickets for SKM Warszawa trains. There is also a combined ZTM - KM - WKD ticket.
} 
Rail in Szczecin, Metropolitan Rail of Podkarpackie in Rzeszów, Wrocław Metropolitan Rail in Wrocław, Łódź Metropolitan Rail in Łódź, BiT City in Bydgoszcz and Torun or Metropolitan Rail in the Upper Silesian Metropolitan Area. In some cases (e.g. Szczecin Metropolitan Rail), additional pairs of tracks are being built and added to the generally accessible infrastructure of PKP PLK S.A. to service metropolitan traffic provided by trains of the regional operator. In turn, the Pomorska Kolej Metropolitalna S.A. project involves the construction of new railway infrastructure in the TriCity metropolitan area by this operator, and then making it available to rail operators, including PKP SKM, which provide services based on their own fares. The operations of local government units result not only from demography, suburbanisation processes, and congestion, but also from the need to meet the challenges of adapting passenger transport to EU environmental priorities [2]. Nevertheless, local government units are doing well despite adequate organisational and financial instruments, not because of them. However, the consequence of the weakness of national regulations in this area is an increased risk in the process of organising this type of transport and its reduced efficiency. For this reason, it would be appropriate for the competent authorities to consider implementing regulations pertinent to the needs in this field. The aim should be to develop and implement solutions in at least three areas:

1) a funding model for an integrated ticketing system (including the so-called combined ticket),

2) organisational and legal cooperation between public transport organisers in the field of organisation and provision of metropolitan transport,

3) financial support from the state budget for the establishment of metropolitan transport by rewarding the cooperation and effectiveness of its organisers.

Assuming the neutrality for the state budget of the proposed changes, the recommendations would require to banish the existing standard of assignment of the cost of a transport service to a specific accounting document, which in this case is a train ticket. Instead, the basis for the settlement of a rail transport service, performed based on a railway ticket integrated with public transport tickets (combine ticket), should be the achievement of certain transport effects. Such an approach in the rail sector is nothing new. Pursuant to Article $38 \mathrm{a}(1)$ of the Act of 28 March 2003 on rail transport [11], under the so-called maintenance contract [48], some of the costs of PKP PLK S.A. which are not costs of direct access to infrastructure are financed by the state. A long-term contract for its maintenance is settled based on indicators, not on costs based on specific accounting documents. The contract itself defines the scope of expenditure that is eligible for financing by the public party. To safeguard the interests of the state budget, the correctness of spending funds in each financial year is verified by an expert auditor. This system replaced the previous approach based on invoices confirming the expenditure incurred, because not all costs could be settled in this way, given that the level of co-financing of PKP PLK S.A.'s operating costs exceeds $50 \%$ of the total. The method for determining the costs eligible for financing by the state budget is set out in the contract for the implementation of the long-term programme: "Financing the costs of managing railway infrastructure aid, including its maintenance and renovation until 2023".

The adoption of an indicative method of accounting for journeys made on an integrated ticket should be based on two basic parameters: the number of passengers transported and the price of this service (instead of a railway ticket cost), considering statutory discounts. In this way, metropolitan areas would be financially interested in implementing integrated fares because, as the number of passengers transported on its basis increases, the compensation they would receive from the state budget (considering the limits provided for it) would increase. Therefore, it would not be an additional source of compensation for local government units. This would be the current refund for statutory reduced fares, financed from an existing source, but slightly differently accounted for. However, this would require a change in the legislation. Pursuant to $₫ 3$ section 1 of the Regulation of Minister of Finance of 17 September 2010 on the subsidy for domestic passenger transport: (...) the basis for calculating the subsidy due is the value of lost fare revenues due to the application of reduced fares, with the completed, documented, and recorded ticket sales (...) [7]. It follows from the current wording of the regulation that these must be tickets issued by a given operator and for a service provided by it, which is impossible with a combined ticket.

The adopted method of calculating the amount of compensation should be as simple and easy to calculate as possible (in terms of data availability). The ratio of persons with certain statutory reduced fares could determine how many transport services (in percentage terms) are deemed to have been provided to persons entitled to a given reduced fare. Thus, it would be the basis for obtaining compensation for lost revenues in metropolitan transport based on a combined ticket. This indicator could either be predetermined by the public authorities or calculated each time based on the organiser's ticket sales structure under the combined ticket, irrespective of the type of transport service (rail, trams, buses etc.).

As a result, the legislator could even somehow force the organisers of a local (municipal) level to integrate rail (metropolitan) fares, because only in- 
tegrated offers, considering statutory reduced fares, would be eligible for settlement with the state budget. The point is not to finance from the state budget only reduced fares under integrated fares, but only the fact that the offers of operators and organisers of rail passenger transport that integrate their fares with public transport in metropolitan areas would be eligible for such financing ${ }^{13}$. However, this requires the involvement of the national legislator so that the combined ticket is an accessible and usable systemic solution, and not just a substitute, created on an ad hoc basis.

For such a solution, the partner for the state budget should be a structure in the form of a metropolitan transport union, as a new public transport organisation form in the urban areas and their functional areas. The union could include local self government units at all levels around a given metropolitan area. It would have a legal personality and could assume some or all powers of the planning and organisation of all the public transport modes of its members. A model for such legal solutions could be the gmina and poviat unions existing in the legal system. Referring these proposals to foreign solutions, it should be emphasised that external ones consist mainly of the functioning of private liability companies (the aforementioned VBB, but also the Czech KODIS, a limited liability company, managing the integrated ODIS ticket sales and settlement system in the MoravianSilesian Region, the equivalent of a Polish voivodeship [41]), or self government associations (German Verkehrsverbund Rhein Ruhr VRR, i.e. the Ruhr Rhine Communication Association associating the district level) [63], but also on the basis of entrusting organisers belonging to other local self governments with the obligation to organise public transport in their own area (e.g. The Czech ROPID, Regional Organiser of Integrated Transport in Prague, which organises transport services in Prague, and on behalf of municipalities, districts and authorities of the Central Bohemian Region, which have entrusted it with the provision of transport services) [55]. A solution like the proposed one is the legal mechanism used, for example, in the French metropolitan area of Lille, where the organisation of transport belongs to the European Metropolitan Association of Lille (Métropole Européenne de Lille, MEL). It is the PT organiser established by law in 1966 embrancing the City of Lille and the local self government units around it, in the northern part of France [46].
The new regulation should be introduced into the PT Act. Its obligatory competence would include the organisation of rail transport, which a metropolitan union is not obliged to do. It should contain the principles of the financing model for a uniform ticketing system and a combined ticket. An alternative solution is to amend the PT Act by obliging the existing form of a metropolitan union to organise and finance rail transport, integrated throughout a metropolitan area with public and suburban (municipal) transport, specifying the source of this financing (including the one indicated above, coming from the state budget for refinancing statutory reduced fares).

The introduction of a metropolitan transport union should involve the implementation of regulations concerning the method of financing metropolitan transport by the gminas and poviats that are members of such union and currently do not have the obligation to finance such services ${ }^{14}$. Legislative amendments should be accompanied by the mentioned amendments to the implementing acts allowing for the indicative settlement of the common ticket.

Solutions regulating the participation of local government units at all levels in the organisation of metropolitan transport should be stimulated by support from the central budget, e.g., by increasing the share of these entities in corporate tax, which has historically been a source of financing rail transport at the local self government level. Otherwise, demographic processes and the lack of financial stimulation will lead to another collapse of the segment of regional transport, financially cannibalized by much more efficient metropolitan transport.

\section{References}

\section{Source materials}

1. Federal Transit Administration U.S. Department of Transportation, 2013 Reporting Year National Transit Database Glossary, September 2013.

2. Communication from the Commission to the European Parliament, the European Council, the Council, the Economic and Social Committee and the Committee of the Regions, The European Green Deal, Brussels, 11.12.2019, COM(2019)640 final.

3. Ministerstwo Funduszy i Polityki Regionalnej, Szczegółowy opis osi priorytetowych Programu Operacyjnego Infrastruktura i Środowisko 2014-2020

\footnotetext{
${ }^{13}$ With the option for the current settlement of receivables for revenues lost from servicing passengers using only non-integrated railway offerings.

${ }^{14}$ Currently, the problem has been dealt with only in the PKM project: it is financed from the following sources: Marshal of Wielkopolska at the level of $85 \%$ of the metropolitan transport costs, gminas $10-15 \%$, and poviats $3.5-6.6 \%$ [21].
} 
[Ministry of Funds and Regional Policy, Detailed description of the priority axes of the Infrastructure and Environment Operational Programme 2014-2020], Warszawa, 19 November 2020.

4. Najwyższa Izba Kontroli [Supreme Audit Office], Informacja o wynikach kontroli „Realizacja zadań publicznych przez spółki tworzone przez jednostki samorzadu terytorialnego [Information on the audit results "Implementation of public tasks by companies created by local government units"], Warszawa, 2014.

5. Plan zrównoważonego rozwoju transportu zbiorowego dla m.st. Warszawy z uwzględnieniem publicznego transportu zbiorowego organizowanego na podstawie porozumień z gminami sąsiadującymi. Załącznik do uchwały Rady m.st. Warszawy $\mathrm{Nr}$ XI/198/2015 z dn. 7 maja 2015 r. [Plan for the sustainable development of public transport for the capital city of Warsaw, including public transport organised based on agreements with neighbouring municipalities. Annex to the resolution of the Council of the capital city of Warsaw No. XI/198/2015 of 7 May 2015.

6. Porozumienie nr GK.031.2.2014 zawarte między Miastem Stołecznym Warszawa a Gminą Legionowo w dniu 2014-02-10 [Agreement no. GK.031.2.2014 concluded between Warsaw and the Legionowo Gmina on 2014-02-10], Dz.U. Województwa Mazowieckiego z dnia 10 lipca 2014 r. poz. 6679.

7. Rozporządzenie Ministra Finansów z dnia 17 września 2010 r. w sprawie dotacji przedmiotowej do krajowych przewozów pasażerskich [Regulation of the Minister of Finance of 17 September 2010 on the subsidy to national passenger transport], Dz.U. z 2020, poz. 1265 .

8. Uchwała nr 105/2019 Rady Ministrów z dnia 24 września 2019 r. w sprawie przyjęcia Strategii Zrównoważonego Rozwoju Transportu do 2030 roku [Resolution No. 105/2019 of the Council of Ministers of 24 September 2019 on the Strategy of Sustainable Transport Development until 2030 adoption], Monitor Polski, 2019,poz. 1054, p. 75.

9. Uchwała Nr 239/2011 Rady Ministrów z dnia 13 grudnia 2011 r. w sprawie przyjęcia Koncepcji Przestrzennego Zagospodarowania Kraju 2030 [Resolution No. 239/2011 of the Council of Ministers of 13 December 2011 on adopting the National Spatial Planning Concept 2030], Monitor Polski 2012, poz. 252.

10. Ustawa z dnia 9 marca 2017 r. o związku metropolitalnym w województwie śląskim [Act of 9 March 2017 on the metropolitan union in the Silesian Voivodeship], Dz.U. z 2017 r., poz. 730.

11. Ustawa $\mathrm{z}$ dnia 28 marca 2003 r. o transporcie kolejowym [Act of 28 March 2003 on railway trans- port], Dz.U. z 2020 r. poz. 1043, 1378, 1778, z 2021 r. poz. $780,784$.

12. Ustawa $z$ dnia 25 czerwca 2009 r. o zmianie ustawy o autostradach płatnych oraz o Krajowym Funduszu Drogowym oraz o zmianie niektórych innych ustaw [Act of 25 June 2009 amending the Act on Toll Motorways and the National Road Fund and amending some other acts], Dz.U. nr 116, poz. 975.

13. Ustawa z dnia 25 września 1981 r. o przedsiębiorstwach państwowych [Act of 25 September 1981 on state enterprises], Dz.U. z 2020 r., poz. 1644.

14. Ustawa z dnia 9 października 2015 r. o związkach metropolitalnych [Act of 09 October 2015 on metropolitan unions], Dz.U. z dnia 18 listopada 2015 r., poz. 1890.

15. Ustawa $\mathrm{z}$ dnia 15 listopada $1984 \mathrm{r}$. Prawo przewozowe [Act of 15 November 1984, Transport Law], Dz.U. z 2020 r. poz. 8.

16. Ustawa z dnia 16 grudnia 2010 r. o publicznym transporcie zbiorowym [Act of 16 December 2010 on public transport], Dz.U. 2020, poz. 1944)1944).

17. Wehmeier S. (ed.): Oxford Advanced Learner's Dictionary of Current English, Oxford 2003.

18.Załącznik do uchwały Nr 425/19 Zarządu Województwa Małopolskiego $\mathrm{z}$ dnia 22 marca 2019 r. dotyczące porozumienia w sprawie współpracy w zakresie rozwoju transportu kolejowego na terenie województwa małopolskiego poprzez budowę nowej linii kolejowej łączącej Miasto Kraków z Gminą Myślenice [Annex to Resolution No. 425/19 of the Board of the Małopolska Voivodeship of 22 March 2019 concerning the agreement on cooperation in the field of railway transport development in the Małopolska Voivodeship through the construction of a new railway line connecting the City of Kraków with the Myślenice Gmina].

19.Załącznik do Uchwały Nr 744/12 Zarządu Województwa Małopolskiego z dnia 28 czerwca 2012 $\mathrm{r}$ „Porozumienie wstępne w przedmiocie wyrażenia woli współdziałania i współpracy między Województwem Małopolskim a lokalnymi jednostkami samorządu terytorialnego przy przygotowaniu i realizacji przedsięwzięcia inwestycyjnego $\mathrm{z}$ zakresu transportu publicznego polegającego na zagospodarowaniu węzłów komunikacyjnych zlokalizowanych w Obszarze Obsługiwanym przez Szybka Kolej Aglomeracyjna" [Annex to Resolution No. 744/12 of the Board of the Małopolska Voivodeship of 28 June 2012 "Initial agreement on expressing the will of co-operation and co-operation between the Małopolska Voivodeship and local government units in the preparation and implementation of an investment project in the field of public transport involving the development of transport hubs located in the Area served by the Fast Metropolitan Railway"]. 


\section{Monographs and presentations}

20. Ciastoń A.: Koleje aglomeracyjne i regionalne w Europie [Metropolitan and regional railways in Europe], TTS Technika Transportu Szynowego, No. $10 / 2007$.

21. Frąckowiak B.: Pełnomocnik Zarządu Stowarzyszenia Metropolia Poznań ds. PKM, Prezentacja pt.: Poznańska Kolej Metropolitalna. Komplementarność, jako klucz do sukcesu, wygłoszona w dniu 25.05.2021 [Representative of the Management Board of the Poznań Metropolis Association for the Poznan Metropolitan Railway, Presentation entitled: Poznań Metropolitan Railway. Complementarity as the key to success].

22. Kajdanek K.: Pomiędzy miastem a wsia. Suburbanizacja na przykładzie osiedli podmiejskich Wroclawia [Between town and country. Suburbanisation on the example of suburban housing estates of Wrocław], Krakow 2011.

23. Kociuba D.: Metropolises and metropolitan areas in Poland: problems of classification and delimitation, 7-th International Conference of PhD Students at University of Miskolc, Hungary, M. Dóbroka, P. Bikfalvi (eds.), Volume: Natural Science, pp. 81-86, September 2010.

24. Kołoś A., Trzepacz P.: Transport, a metropolitalność - przykład Berlina [Transportation and metropolitanity - the example of Berlin], Instytut Geografii i Gospodarki Przestrzennej Uniwersytetu Jagiellońskiego, Prace Geograficzne zeszyt 125, Kraków 2010.

25. Koźlak A.: Kolej aglomeracyjna jako podstawa systemu komunikacyjnego obszarów metropolitalnych $w$ Polsce [Metropolitan railway as the basis of the transport system of metropolitan areas in Poland] (in:) M. Michałowska (ed.), Współczesne uwarunkowania rozwoju transportu $w$ regionie [Contemporary determinants of transport development in the region], Katowice 2013.

26.Lalik M.: Tabor szynowy do przewozów aglomeracyjnych [Railway stock for metropolitan transport], Railway Research Institute, Problemy Kolejnictwa, zeszyt 148, Warszawa, 2009.

27.Lisowski A., Grochowski M.: Procesy suburbanizacji. Uwarunkowania, formy i konsekwencje [Suburbanisation processes. Determinants, forms, and consequences] (in:) Ekspertyzy do koncepcji przestrzennego zagospodarowania kraju 2008-2033 [Expert opinion on the National Spatial Planning Concept 2008-2033], Tom 1, Ministerstwo Rozwoju Rolnictwa, Warszawa, 2008.

28. Mandri-Perrot A.: Private Sector Participation in Light Rail-Light Metro Transit Initiatives, The World Bank, Washington, 2010.

29. Mazur B.: Finansowanie ulg $w$ przewozach pasażerskich - wybrane zagadnienia, prezentacja wy- głoszona w trakcie IV. Ogólnopolskiej Konferencji Naukowej „Konsument na rynku kolejowych przywozów pasażerskich" [Financing of reduced fares in passenger transport - selected issues, presentation], presentation delivered during the 4th National Scientific Conference "Consumer on the market of railway passenger transport”, 26.04.2017 Łódź.

30. Raczyńska-Buława E.: Systemy kolei aglomeracyjnych $w$ Polsce [Metropolitan rail systems in Poland], TTS Technika Transportu Szynowego $7-8 / 2015$.

31. Romanowski M.: Cel spółki i charakter prawny umowy spótki [The company objective and the legal nature of the company deed], Studia Prawa Prywatnego nr 03/2015.

32.Śleszyński P.: Delimitacja Miejskich Obszarów Funkcjonalnych stolic województw [Delimitation of Urban Functional Areas of Capital Cities of Voivodeships], Przegląd Geograficzny, Tom 85, nr 2, Warszawa, 2013.

33. The World Bank, Removing Barriers to Public Transport Integration in Poland. Key Directions of Change, Washington DC 2016.

34.Żurkowski A.: Intermodalne uwarunkowania rytmizacji przewozów pasażerskich [Intermodal determinants of passenger transport regularity], Logistyka nr 3/2012.

\section{Internet sources:}

35.http://bustramwajkolej.pl/ [accessed on: 4.07.2021].

36.https://dopiewo.pl/aktualnosci/2017-11-18/samorzady-wypracowaly-model-finansowania-pkm [accessed on: 19.07.2021].

37.https://gazeta.myslenice.pl/z-krakowa-domyslenic-koleja-jest-porozumienie, [accessed on: 11.08.2021].

38.https://www. mamnewsa.pl/gospodarka/ szybka-kolej-do-krakowa-jest-porozumieniesamorzadowcow [accessed on: 11.08.2021].

39. Official website of the Berlin Transport Company: https://www.bvg.de/en/Travel-information/Localrail [accessed on: 21.11.2020].

40. Official website of InnoBaltica Sp. z o.o. http://www. innobaltica.pl/1_18_o-ulgach.html [accessed on: 07.12.2020].

41. Official website of KODIS: https://www.kodis.cz/ en/dopravni-infocentra/about-us/87/about-us. html [accessed on 10.07.2021].

42. Official website of Koleje Małopolskie: https:// malopolskiekoleje.pl/index.php/podroz/37-biletyhonorowane [accessed on: 25.07.2021].

43. Official website of Koleje Wielkopolskie sp. z o.o.: https://koleje-wielkopolskie.com.pl/dla-pasazera/ honorowanie-biletow/ [accessed on: 4.07.2021]. Official website of Koleje Wielkopolskie sp. z o.o.: https://koleje-wielkopolskie.com.pl/dla-pasaze- 
ra/oferty-specjalne/, zakładka bustramwajkolej.pl [accessed on: 4.07.2021].

44. Official website of the European Commission https://ec.europa.eu/regional_policy/en/policy/ what/glossary/p/partnership-agreement [accessed on: 07.12.2020]

45. Official website of MEL: https://www.lillemetropole. fr/en/your-daily/your-daily [accessed on: 10.07.2021].

46. Official website of the Ministry of Funds and Regional Policy: https://www.funduszeeuropejskie. gov.pl/strony/o-funduszach/zasady-dzialaniafunduszy/zintegrowane-inwestycje-terytorialne/ [accessed on: 04.12.2020].

47. Official website of the Ministry of Infrastructure: https://malopolskiekoleje.pl/index.php/podroz/37bilety-honorowane [accessed on: 25.07.2021].

48. Official website (archived) of the Ministry of Investment and Development: https://archiwum. miir.gov.pl/strony/zadania/polityka-rozwojukraju/zarzadzanie-rozwojem-kraju/koncepcjaprzestrzennego-zagospodarowania-kraju/ [accessed on: 02.12.2020].

49. Official website (archived) of the Ministry of Investment and Development: https://miir.bip.gov. pl/strategie-rozwoj-regionalny/17847_strategie. html [accessed on: 02.12.2020].

50. Official website of National Rail: https://ojp.nationalrail.co.uk/service/timesandfares/KGX/ HAY/021220/2230/dep\#outwardJump [accessed on: 02.12.2020].

51. Official website of POLREGIO sp. z o.o.: https://polregio.pl/pl/dla-podroznych/informacje/wielkopolskie-przyspiesza-z-polregio/ [accessed on: 4.07.2021].

52. Official website of Poznań Metropolitan Rail http://www.kolej.metropoliapoznan.pl/, accessed on 4.07.2021.
53. Official website of PV: https://www.pv.lv/en/aboutus/ [accessed on: 24.11.2020].

54. Official website of ROPID: https://pid.cz/o-organizaci/ o-organizaci-ropid/ [accessed on:10.07.2021].

55. Official website of S-Bahn Berlin GmbH (subsidiary of DB Regio AG) https://sbahn.berlin/ en/tickets/the-vbb-fare-explained/ [accessed on: 24.11.2020].

56. Official website of Stowarzyszenie Integracji Stołecznej Komunikacji http://siskom.waw.pl/kpparkingi.htm [accessed on: 02.12.2020].

57. Official website of Stowarzyszenie Metropolia Poznań: http://www.metropoliapoznan.pl/strona,4,poznanska_kolej_metropolitalna.html [accessed on: 4.07.2021].

58. Official website of Stowarzyszenie Metropolia Poznań: http://metropoliapoznan.pl/strona,17,rada_metropolii.html [accessed on: 4.07.2021].

59. Official website of Stowarzyszenie na rzecz Niepełnosprawnych SPES: https://www.spes.org.pl/twoje-prawa/transport-i-ulgi-w-przejazdach [accessed on: 07.12.2020].

60. Official website of Transport for London https:// tfl.gov.uk/fares/how-to-pay-and-where-to-buytickets-and-oyster/pay-as-you-go/oyster-pay-asyou-go?intcmp $=55536$ [accessed on: 21.11.2021].

61. Official website of the Office for Railway Transport: https://www.utk.gov.pl/pl/pasazerowie/kolejowefaq/przejazdy-bezplatne/14418,Przejazdy-bezplatne-i-ulgowe.html [accessed on: 07.12.2020].

62. Official website of VRR: https://www.vrr.de/en/ vrr/an-overview/ [accessed on: 10.07.2021].

63. Official website of Vy: https://www.vy.no/en/traffic-and-routes/stations-and-network-maps [accessed on: 24.11.2020].

The content of the article is the opinion of the authors and does not constitute the official position of the institutions in which they are employed. 